\title{
Payments for ecosystem services in the tropics: a closer look at effectiveness and equity L Calvet-Mir $^{1,2}$, E Corbera ${ }^{1,3}$, A Martin $^{4}$, J Fisher ${ }^{5}$ and N Gross-Camp ${ }^{4}$
}

\begin{abstract}
We undertake a review of academic literature that examines the effectiveness and equity-related performance of PES initiatives targeting biodiversity conservation in tropical and sub-tropical countries. We investigate the key features of such analyses as regards their analytical and methodological approach and we identify emerging lessons from PES practice, leading to a new suggested research agenda. Our results indicate that analyses of PES effectiveness have to date focused on either ecosystem service provision or habitat proxies, with only half of them making explicit assessment of additionality and most describing that payments have been beneficial for land cover and biodiversity. Studies evaluating the impact of PES on livelihoods suggest more negative outcomes, with an uneven treatment of the procedural and distributive considerations of scheme design and payment distribution, and a large heterogeneity of evaluative frameworks. We propose an agenda for future PES research based on the emerging interest in assessing environmental outcomes more rigorously and documenting social impacts in a more comparative and contextually situated form.
\end{abstract}

\footnotetext{
Addresses

${ }^{1}$ Institute of Environmental Science and Technology (ICTA), Universitat Autònoma de Barcelona, 08193 Bellaterra, Spain

${ }^{2}$ Internet Interdisciplinary Institute (IN3), Universitat Oberta de Catalunya, Spain

${ }^{3}$ Department of Economics \& Economic History, Universitat Autònoma de Barcelona, 08193 Bellaterra, Spain

${ }^{4}$ School of International Development, University of East Anglia, NR47TJ Norwich, UK

${ }^{5}$ School of Geosciences, University of Edinburgh, EH8 9XP Edinburgh, UK

Corresponding author: Corbera, E (esteve.corbera@uab.cat)
}

Current Opinion in Environmental Sustainability 2015, 14:150-162

This review comes from a themed issue on Open issue

Edited by Eduardo S Brondizio, Rik Leemans and William D Solecki

Received 17 December 2014; Revised 26 May 2015; Accepted 01 June 2015

http://dx.doi.org/10.1016/j.cosust.2015.06.001

1877-3435/C 2015 Elsevier B.V. All rights reserved.

\section{Introduction}

Payments for Environmental or Ecosystem Services (PES) have become a means to promote biodiversity conservation and rural development, particularly in tropical and sub-tropical regions [1]. National or regional PES programs are currently implemented in countries like Costa Rica, Mexico, Ecuador, Vietnam, China, South Africa or the United States, while smaller regional programs have been tested in European countries like Germany and the UK [2]. Small-scale PES projects promoted by non-governmental organizations to enhance watershed protection and biodiversity conservation, as well as to protect carbon reservoirs and sinks under the umbrella of the United Nations Framework Convention on Climate Change - as carbon offset and REDD+ projects - have also been developed worldwide [3]. These programs and projects have usually become part of a conservation policy mix, in which the direct incentives provided by PES co-exist with more traditional regulatory conservation approaches [4].

Research examining the performance of PES schemes has increased exponentially over the past decade. Academic PES reviews to date have focused on a few programs and projects $\left[5^{\circ}\right]$, have had a single topical or geographical focus [6-11], or have relied mostly on qualitative information provided by project managers and conservation organizations [12]. These analyses have sought to distill lessons on what PES schemes have achieved in environmental and livelihood terms, to explain these achievements, and to analyze what could be done to improve design and performance.

Our review aims at a better understanding of conservation interventions but is distinctive from existing reviews in at least three ways. First, we focus only on peer-reviewed publications analyzing ongoing - not planned or potential - PES initiatives implemented in tropical and subtropical countries across Asia, Africa and Latin America. These regions contain the highest concentrations of biodiversity on the planet and are experiencing rapid change that is leading to the loss of biodiversity $[13,14]$. These regions also contain deep, multifaceted poverty [15] where the burden of ecosystem protection is often borne by those least able to afford it [16]. Second, we are principally interested in understanding if researchers have considered PES schemes to be effective both in achieving their biodiversity and environment-related goals, that is, if they have achieved the goals set by the 
correspondent PES program or project, and to be efficient in their use of financial resources, given that PES have often been praised as cost-effective alternatives compared to more conventional conservation instruments $[17,18]$. Finally, we are interested in highlighting if researchers have considered PES schemes to be equitable, that is, if they have involved poor people in their design and implementation and if they have benefited participants equally. Therefore our objective is not to judge by ourselves if the PES cases reviewed are effective, efficient and equitable but instead to annotate what the reviewed article authors consider such cases to be.

We also acknowledge that the equity judgments of the authors in the reviewed articles can be considered less 'objective' than effectiveness results, since such judgments may depend on the scholars' approach to the concept and the potential for conflict between her views and those of local people. However, we think that some aspects of equity, for example the distribution of jobs or income derived from PES implementation, can indeed be measurable and thus presented with objective data, while other equity-related criteria might be more prone to subjectivity, such as the existence of conflicts or participation levels in PES design and implementation.

Nonetheless, we believe that all aspects deserve attention given that PES is part of a broader international environmental governance agenda that aims to transform the distribution of rights and responsibilities in resource management across the world, and particularly in the global South [19]. An equity focus is thus important to understand if PES could serve as a means of redistributing the costs and benefits of conservation in a way that alleviates poverty and minimizes social conflict $\left[20,21^{\bullet \bullet}\right]$. Finally, throughout our analysis, we investigate the methods employed by scholars to draw conclusions on economic and ecological effectiveness and equity and examine if methods and the outcomes described are related to each other.

Overall, the findings and the resulting discussion contribute toward establishing an agenda for future PES research by identifying data and analytical gaps, and pointing to the opportunities and challenges lying ahead to develop more robust research approaches. The results are also relevant for PES practitioners to the extent we offer an overview of existing PES schemes in sub-tropical and tropical countries, and we call for partnerships to better design and monitor PES worldwide.

\section{Methods}

We compiled a database of peer-reviewed literature in Scopus for articles published between January 2003 the year of the publication of the first Millennium Ecosystem Assessment Report - and December 2013, searching for the terms 'payment for environmental services' or 'payment for ecosystem services' and 'conservation' anywhere in title, abstract or keywords, and the term 'tropical' anywhere in the text. The results returned 213 ('environmental') and 200 ('ecosystem') articles, of which over $80 \%$ had been published between 2009 and 2013, indicating the growing popularity of the subject and the increase in scholarly attention to PES.

We targeted journal contributions that (i) analyzed one or more implemented PES initiatives in tropical or subtropical countries, excluding Australia for being a highly developed country and China because half the country falls outside the sub-tropics; (ii) focused on initiatives with direct or indirect biodiversity conservation objectives, that is, they targeted the conservation or restoration of an ecosystem, or the provision of related ecosystem service(s), and (iii) examined PES effectiveness and/or equity considerations, such as the degree to which environmental objectives have been achieved, people's access to project activities, participation in design and implementation, and the impact and distribution of incentives. We excluded articles developing a conceptual framework, argument or model related to PES theory, practice or the targeting of payments [4,22-30]; focusing on analytical issues unrelated to effectiveness and equity, such as motivations to participate in PES [31-33]; and those that did not include a purposive analysis of case studies, such as summary articles in special issues, the above mentioned PES reviews, and articles with anecdotal evidence on PES implementation to illustrate a related argument [34-37].

Our final database includes 34 articles focused on 29 PES programs and projects (Table 1). The World Bank's sponsored RISEMP project has been implemented in different countries and we have considered each country scheme as a separate case study. Thirty articles examine only one PES initiative [38-47,48 ${ }^{\bullet}, 49-54$, $55^{\bullet \bullet}, 56,57^{\bullet \bullet}, 58-66,67^{\bullet \bullet}$ ], one paper focuses on two cases [68], and three analyze three or more schemes in the same article [69-71]. From each of these contributions, we extracted the following information to provide some background on the location and typology of the PES schemes analyzed: location of the researched PES scheme (continent, country), scheme reach (national, local), type of service being paid for (well-defined ecosystem service, proxy), and type of land tenure where it has been implemented (private, public, communal). We also recorded each article's authors, year of publication, the PES scheme analyzed, the location of the scheme the article is focusing on, the author(s)' analytical objective(s), methods, the characterization of effectiveness and/or equity by the author(s), and PES outcomes reported. For the latter, and to reduce potential bias in article assessment, we extracted the relevant text in which the authors explicitly referred to effectiveness, perceived level of additionality - i.e. the extent to 


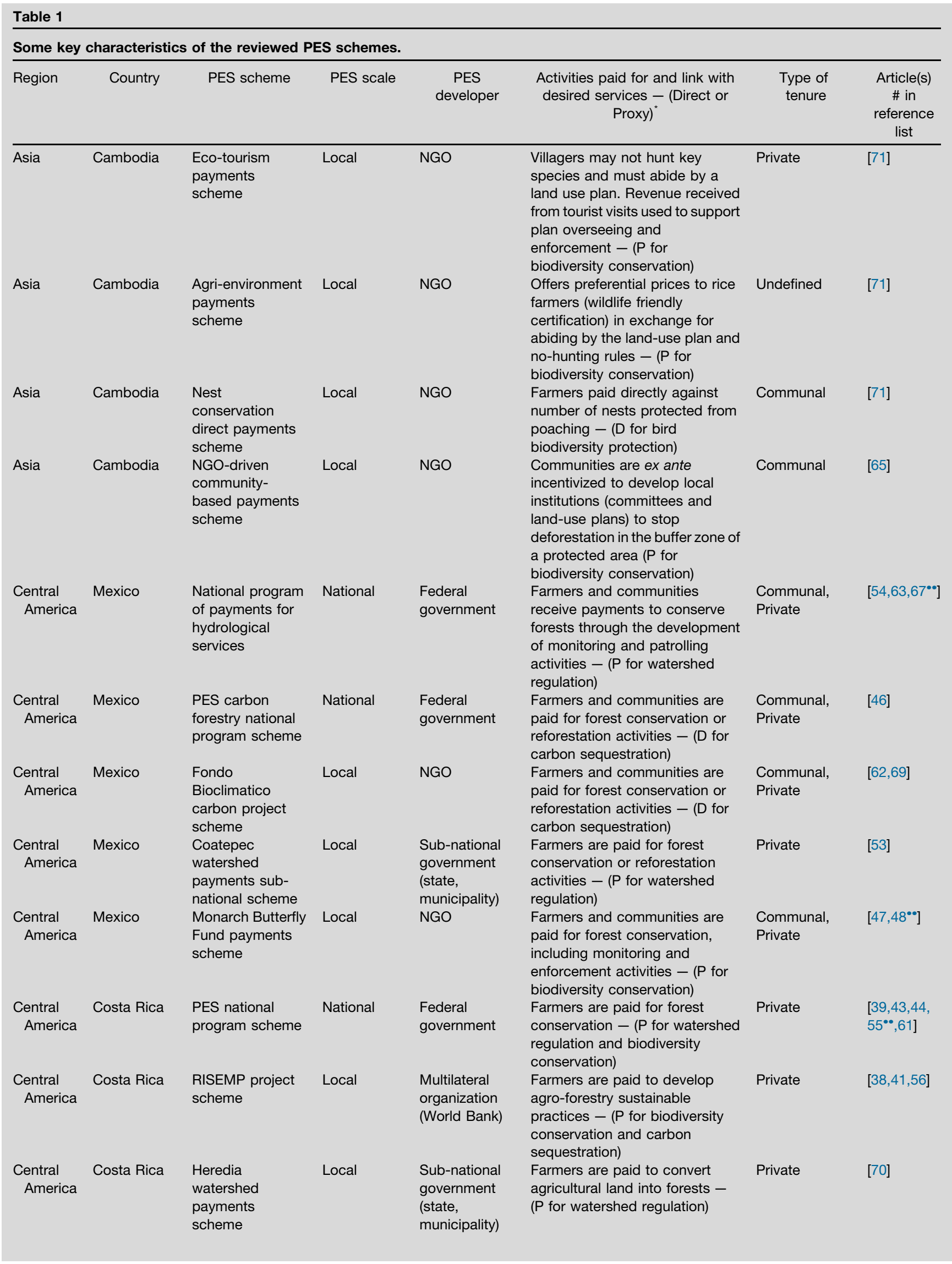


Table 1 (Continued)

\begin{tabular}{|c|c|c|c|c|c|c|c|}
\hline Region & Country & PES scheme & PES scale & $\begin{array}{c}\text { PES } \\
\text { developer }\end{array}$ & $\begin{array}{c}\text { Activities paid for and link with } \\
\text { desired services - (Direct or } \\
\text { Proxy) }\end{array}$ & $\begin{array}{c}\text { Type of } \\
\text { tenure }\end{array}$ & $\begin{array}{l}\text { Article(s) } \\
\# \text { in } \\
\text { reference } \\
\text { list }\end{array}$ \\
\hline $\begin{array}{l}\text { Central } \\
\text { America }\end{array}$ & Nicaragua & $\begin{array}{l}\text { RISEMP project } \\
\text { scheme }\end{array}$ & Local & $\begin{array}{l}\text { Multilateral } \\
\text { organization } \\
\text { (World Bank) }\end{array}$ & $\begin{array}{l}\text { Farmers are paid to develop } \\
\text { silvopastoral management } \\
\text { practices - ( } \mathrm{P} \text { for biodiversity } \\
\text { conservation and carbon } \\
\text { sequestration) }\end{array}$ & Private & {$[38,40,49]$} \\
\hline $\begin{array}{l}\text { Central } \\
\text { America }\end{array}$ & Nicaragua & $\begin{array}{l}\text { San Pedro del } \\
\text { Norte watershed } \\
\text { payments } \\
\text { scheme }\end{array}$ & Local & $\begin{array}{l}\text { Sub-national } \\
\text { government } \\
\text { (state, } \\
\text { municipality) }\end{array}$ & $\begin{array}{l}\text { Farmers are paid to convert } \\
\text { agricultural land into forests - } \\
\text { (P for watershed regulation) }\end{array}$ & Private & [70] \\
\hline $\begin{array}{l}\text { Central } \\
\text { America }\end{array}$ & Guatemala & $\begin{array}{l}\text { Las Escobas } \\
\text { watershed } \\
\text { payments } \\
\text { scheme }\end{array}$ & Local & NGO & $\begin{array}{l}\text { Enforced conservation and } \\
\text { adoption of SFM and sustainable } \\
\text { agricultural practices by } \\
\text { protected area inhabitants - } \\
\text { (P for biodiversity conservation } \\
\text { and watershed regulation) }\end{array}$ & $\begin{array}{l}\text { Public (held in } \\
\text { trust by NGO) }\end{array}$ & [69] \\
\hline $\begin{array}{l}\text { Central } \\
\text { America }\end{array}$ & Belize & $\begin{array}{l}\text { Rio Bravo carbon } \\
\text { project scheme }\end{array}$ & Local & NGO & $\begin{array}{l}\text { Forest conservation against a } \\
\text { deforestation and degradation } \\
\text { baseline scenario - ( } \mathrm{D} \text { for } \\
\text { carbon emissions avoided) }\end{array}$ & $\begin{array}{l}\text { Public (held in } \\
\text { trust by NGO) }\end{array}$ & [69] \\
\hline $\begin{array}{l}\text { Central } \\
\text { America }\end{array}$ & Honduras & $\begin{array}{l}\text { Jesus de Otoro } \\
\text { watershed } \\
\text { payments } \\
\text { scheme }\end{array}$ & Local & $\begin{array}{l}\text { Sub-national } \\
\text { government } \\
\text { (state, } \\
\text { municipality) }\end{array}$ & $\begin{array}{l}\text { Farmers are paid to convert } \\
\text { agricultural lands into forests and } \\
\text { develop organic agriculture - } \\
\text { (P for water regulation) }\end{array}$ & Private & [70] \\
\hline $\begin{array}{l}\text { South } \\
\text { America }\end{array}$ & Bolivia & $\begin{array}{l}\text { Los Negros } \\
\text { watershed } \\
\text { payments } \\
\text { scheme }\end{array}$ & Local & NGO & $\begin{array}{l}\text { Farmers are paid for avoiding } \\
\text { forest conversion into } \\
\text { agriculture - ( } \mathrm{P} \text { for water } \\
\text { regulation and biodiversity } \\
\text { conservation) }\end{array}$ & Private & [42] \\
\hline $\begin{array}{l}\text { South } \\
\text { America }\end{array}$ & Bolivia & $\begin{array}{l}\text { Noel Kempff } \\
\text { climate action } \\
\text { project scheme }\end{array}$ & Local & NGO & $\begin{array}{l}\text { Forest conservation against a } \\
\text { deforestation and degradation } \\
\text { baseline scenario - ( } D \text { for } \\
\text { carbon emissions avoided) }\end{array}$ & Undefined & [68] \\
\hline $\begin{array}{l}\text { South } \\
\text { America }\end{array}$ & Colombia & $\begin{array}{l}\text { RISEMP project } \\
\text { scheme }\end{array}$ & Local & $\begin{array}{l}\text { Multilateral } \\
\text { organization } \\
\text { (World Bank) }\end{array}$ & $\begin{array}{l}\text { Farmers are paid to develop } \\
\text { silvopastoral management } \\
\text { practices }-(\mathrm{P} \text { for biodiversity } \\
\text { conservation and carbon } \\
\text { sequestration) }\end{array}$ & Private & [38] \\
\hline $\begin{array}{l}\text { South } \\
\text { America }\end{array}$ & Colombia & $\begin{array}{l}\text { Oak biological } \\
\text { corridor } \\
\text { payments } \\
\text { scheme }\end{array}$ & Local & NGO & $\begin{array}{l}\text { Farmers are paid per hectare to } \\
\text { promote forest conservation by } \\
\text { switching to more sustainable } \\
\text { silvopastoral pasture } \\
\text { management practices that } \\
\text { would increase milk production } \\
\text { and maintain the remaining } \\
\text { forests - ( } P \text { for biodiversity } \\
\text { conservation) }\end{array}$ & Private & [58] \\
\hline $\begin{array}{l}\text { South } \\
\text { America }\end{array}$ & Brazil & $\begin{array}{l}\text { Bolsa Floresta } \\
\text { payments } \\
\text { program scheme }\end{array}$ & Sub-national & $\begin{array}{l}\text { Sub-national } \\
\text { government } \\
\text { (state, } \\
\text { municipality) }\end{array}$ & $\begin{array}{l}\text { Households are paid a monthly } \\
\text { fee (regardless of environmental } \\
\text { additionality level) to reduce } \\
\text { conversion of primary forests on } \\
\text { their lands, with additional } \\
\text { support provided for income- } \\
\text { generating activities that do not } \\
\text { rely on deforestation - (P for } \\
\text { biodiversity conservation) }\end{array}$ & $\begin{array}{l}\text { Communal, } \\
\text { Private }\end{array}$ & {$[60,68]$} \\
\hline $\begin{array}{l}\text { South } \\
\text { America }\end{array}$ & Ecuador & $\begin{array}{l}\text { Socio Bosque } \\
\text { payments } \\
\text { program scheme }\end{array}$ & National & $\begin{array}{l}\text { Federal } \\
\text { government }\end{array}$ & $\begin{array}{l}\text { Farmers or communities are paid } \\
\text { a biannual fee related to the size } \\
\text { of their forests to be protected. } \\
\text { They commit to avoid land-use } \\
\text { change, hunting for commercial } \\
\text { purposes and to report third } \\
\text { party invasions - (P for } \\
\text { biodiversity conservation and } \\
\text { watershed regulation) }\end{array}$ & $\begin{array}{l}\text { Communal, } \\
\text { Private }\end{array}$ & {$[64,66]$} \\
\hline
\end{tabular}




\begin{tabular}{|c|c|c|c|c|c|c|c|}
\hline Region & Country & PES scheme & PES scale & $\begin{array}{c}\text { PES } \\
\text { developer }\end{array}$ & $\begin{array}{c}\text { Activities paid for and link with } \\
\text { desired services - (Direct or } \\
\text { Proxy) }\end{array}$ & $\begin{array}{c}\text { Type of } \\
\text { tenure }\end{array}$ & $\begin{array}{l}\text { Article(s) } \\
\# \text { in } \\
\text { reference } \\
\quad \text { list }\end{array}$ \\
\hline $\begin{array}{r}\text { Central } \\
\text { Africa }\end{array}$ & Rwanda & $\begin{array}{l}\text { Nyungwe national } \\
\text { park payments } \\
\text { scheme }\end{array}$ & Local & NGO & $\begin{array}{l}\text { Households are paid to refrain } \\
\text { from illicitly collecting forest } \\
\text { products }-(P \text { for biodiversity } \\
\text { conservation) }\end{array}$ & Undefined & {$\left[57^{\circ \bullet}\right]$} \\
\hline $\begin{array}{l}\text { Southern } \\
\text { Africa }\end{array}$ & Madagascar & $\begin{array}{l}\text { Mantandia PES } \\
\text { project scheme }\end{array}$ & Local & NGO & $\begin{array}{l}\text { Farmers are paid to reduce land- } \\
\text { use change and to develop } \\
\text { forestation activities - ( } \mathrm{P} \text { for } \\
\text { biodiversity conservation and } \\
\text { carbon sequestration) }\end{array}$ & Public & [50] \\
\hline $\begin{array}{l}\text { Southern } \\
\text { Africa }\end{array}$ & Tanzania & $\begin{array}{l}\text { Uluguru } \\
\text { mountains } \\
\text { watershed } \\
\text { payments } \\
\text { scheme }\end{array}$ & Local & NGO & $\begin{array}{l}\text { Farmers are paid to implement } \\
\text { and maintain a set of specified } \\
\text { soil conservation measures, such } \\
\text { as agro-forestry, reforestation, } \\
\text { grass strip planting and terrace } \\
\text { development - (P for watershed } \\
\text { regulation) }\end{array}$ & Private & [59] \\
\hline $\begin{array}{l}\text { Southern } \\
\text { Africa }\end{array}$ & South Africa & $\begin{array}{l}\text { Working for Water } \\
\text { payments } \\
\text { program }\end{array}$ & National & $\begin{array}{l}\text { Federal } \\
\text { government }\end{array}$ & $\begin{array}{l}\text { External contractors employing } \\
\text { farmers and communities are } \\
\text { paid to remove alien vegetation } \\
\text { species to reduce the presence } \\
\text { of invasive plants on country's } \\
\text { scarce water resources - (P for } \\
\text { watershed regulation and } \\
\text { biodiversity conservation) }\end{array}$ & Undefined & [45] \\
\hline $\begin{array}{l}\text { Southern } \\
\text { Africa }\end{array}$ & Namibia & $\begin{array}{l}\text { Community- } \\
\text { based NRM } \\
\text { payments } \\
\text { program }\end{array}$ & National & $\begin{array}{l}\text { Federal } \\
\text { government }\end{array}$ & $\begin{array}{l}\text { Farmers and communities } \\
\text { receive a share of benefits from } \\
\text { photographic safaris and trophy } \\
\text { hunting, as well as they are } \\
\text { incentivized for protecting wildlife } \\
\text { and other natural resources - } \\
\text { (P for wildlife conservation) }\end{array}$ & Communal & [52] \\
\hline $\begin{array}{l}\text { Southern } \\
\text { Africa }\end{array}$ & Mozambique & $\begin{array}{l}\text { Nhambita carbon } \\
\text { project scheme }\end{array}$ & Local & NGO & $\begin{array}{l}\text { Farmers are paid to plant trees on } \\
\text { the farm (boundaries or in mixed } \\
\text { rows along with crops) - ( } D \text { for } \\
\text { carbon sequestration levels by } \\
\text { planted species) }\end{array}$ & Undefined & [51] \\
\hline
\end{tabular}

We indicate here the activity for which targeted landowners are paid for, and we note if payments are directly related to the measurement of the desired ecosystem services.

which payments result in environmental outcomes that would not have occurred otherwise-, cost-effectiveness, equity, existence of conflicts and perceived legitimacy. Such text was then summarized for explanatory purposes - appearing as 'Outcome explained' data in Supplementary Tables 1 and 2.

\section{PES for biodiversity conservation in tropical and sub-tropical regions \\ Location and typology of PES schemes}

Table 1 shows that the 29 PES schemes examined are not evenly distributed across tropical and sub-tropical regions but concentrated in Central and South America, and less in sub-Saharan Africa. Mexico, Cambodia and Costa Rica have the highest number of PES schemes, with all schemes present in Cambodia being designed by NGOs and developed at local scales. The Costa Rican PES national program is analyzed in seven articles, Mexico's national watershed payments program in four articles and the World Bank's silvopastoral RISEMP project in three. Consistent with other reviews $[8,11]$, most PES schemes have been designed and promoted by NGOs that, in most cases, have received seed financial support from international donors. National (6) or sub-national governments, including states and municipalities (5), have promoted eleven of the 29 PES schemes in our database. Logically, national governments have supported schemes of national reach, while sub-national and local governments have promoted schemes affecting areas within their administrative boundaries, for example, the Bolsa Floresta scheme promoted by the Brazilian Amazonas state government $[60,68]$ or the watershed payment scheme in the Mexican municipality of Coatepec [53].

Most analyses report that schemes reward landowners against the provision of land-use activities that constitute a proxy of the desired ecosystem services. The exception are project schemes linked to voluntary carbon markets 
(e.g. Belize, Mexico), which need to monitor and accurately quantify carbon to participate in such markets $[46,51,62,68,69]$, or niche-based initiatives concentrating on very particular services, such as bird nest protection against poaching [71]. Tenure conditions underlying each PES scheme differ across countries and according to local realities. In Mexico, for example, national and local schemes supporting forest conservation and management - to provide carbon and watershed services - target lands under communal and private property as most forests are administered by communities who hold these in common or have divided up their lands across households. This is also the case of programs with the same or complementary objectives (biodiversity conservation) in Brazil and Ecuador. This contrasts with the Costa Rican case, where forests are generally owned privately and payments strictly channeled to individual landowners.

PES schemes with a strong focus on sustainable agricultural practices or agro-forestry as a proxy for biodiversity conservation or watershed regulation target private, household-managed lands in order to link practices, outcomes and payments more directly $[38,40,42,51,58$, $59,62,70]$. When PES schemes are developed on public lands, NGOs manage targeted lands in trust or operate jointly with the government in the design and implementation of the scheme [69]. In this regard, payment recipients can include communities and households living within a protected area (e.g. the cases of Cambodia and
Guatemala) or the NGO alone (e.g. the case of Belize). It is worth highlighting that six articles in our database did not specify the underlying tenure conditions of the PES scheme and we were only able to infer those in one of the six cases because the correspondent scheme (i.e. Costa Rica's PES national program) had been described extensively in other contributions.

\section{Effectiveness}

Figure 1 (see Supplementary Table 1 for extended information) includes 26 articles analyzing the effectiveness of 24 different PES schemes. However, the figure has 30 analytical observations (\# bullet points) because some articles examine more than one PES scheme. The variable chosen to infer effectiveness and the methods for data collection vary across case studies. Scholars analyze PES effectiveness in terms of (i) changes in the level of ecosystem service provision, that is, if the service targeted increases or decreases; (ii) changes in land-use or habitat provision, that is, if payments maintain or expand the type of land-use or habitat that is used as a proxy of ecosystem service delivery; or (iii) the combination of both variables. Studies focused on service provision levels rely on perceptions of PES actors and/or secondary data provided by project managers, ongoing field monitoring of biodiversity and ecosystem services in PES areas over time [52,71], and the spatial overlap of PES areas with landscapes providing critical ecosystem services [50] to infer effectiveness. Authors concerned with changes in land use

\section{Figure 1}

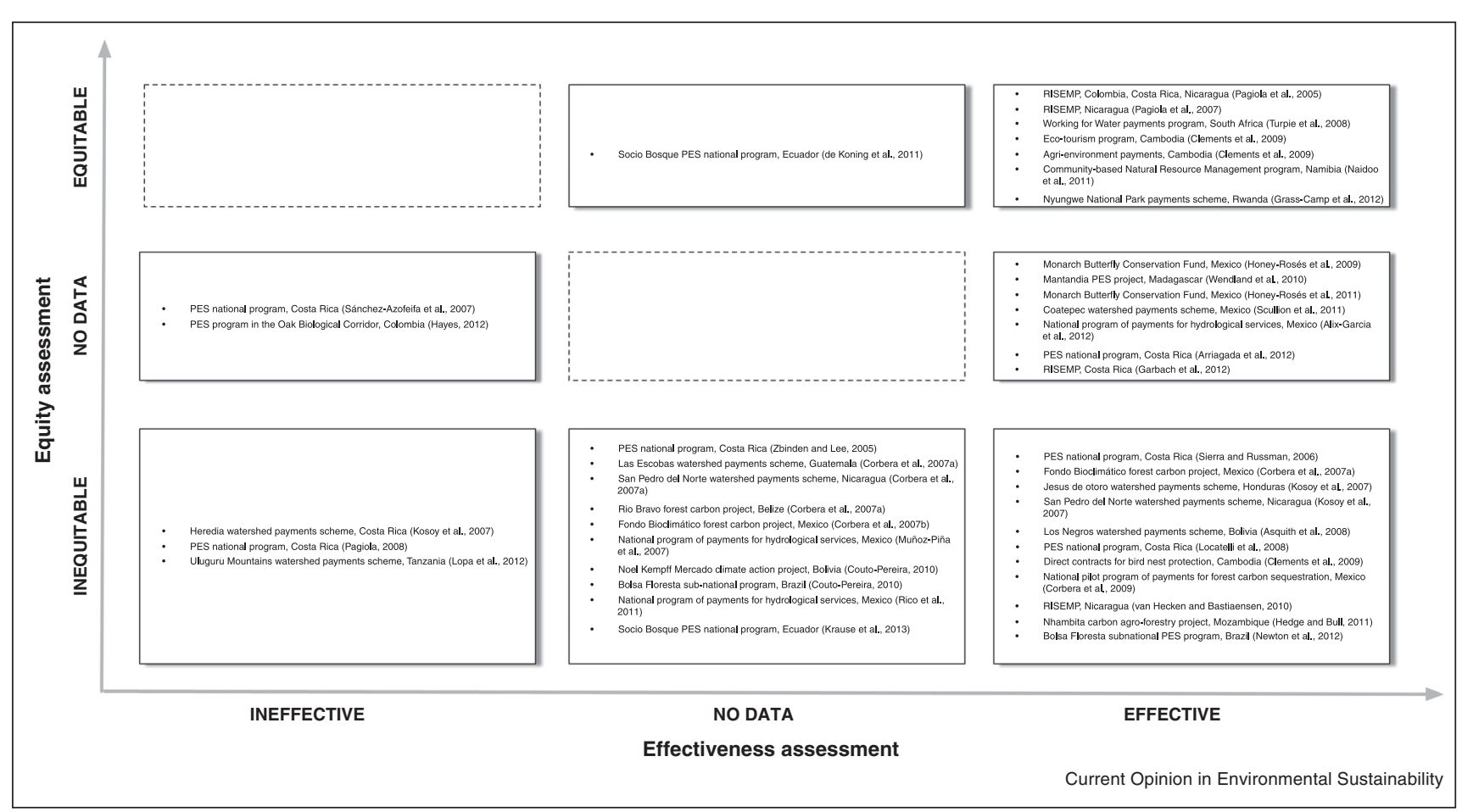

The reviewed articles classified according to their effectiveness and equity outcomes. 
rely on GIS data, including ground-truthing [45] and econometric modeling, such as matching or differencein-difference regressions $\left[39,41,47,48^{\bullet \bullet}, 53,55^{\bullet \bullet}\right]$, actor perceptions and behavioral change $\left[43,57^{\circ \bullet}\right]$, and secondary project data [44]. Authors concerned with both dimensions draw on indices to monitor changes in service provision and habitat quality across different types of land uses [40,49,71,72,42], as well as on GIS and biophysical monitoring of service delivery [59].

Within the PES schemes that have been judged as effective, there are both government-led programs implemented at national scale $\left[39,43,45,52,54,55^{\circ}, 60,70\right]$ and small-scale initiatives, driven by NGOs and other donors $\left[40,46,47,48^{\bullet \bullet}, 49-51,53,56,57^{\bullet \bullet}, 58,69,71,72,42\right]$. Cases described as non-effective also include a variety of typologies and implementation scales [41,44,59,60,70]. Only seven studies have used control groups of non-PES targeted areas or non-participants to account for confounding factors, such as biophysical, socio-economic, political or institutional factors that may be influencing PES performance $\left[39,41,47,48^{\bullet \bullet}, 51,53,54,55^{\bullet \bullet}\right]$.

Costa Rica's national PES scheme has been described by some as effective $\left[39,55^{\circ}\right]$ and by others as ineffective [41], depending on the selected geographical region and the methods employed. The success of PES cases in environmental terms has been related to ecological conditions, for example, a strong linkage between PES activities and ecosystem service delivery $[45,42]$, but mostly to scheme design and its interplay with the socio-ecological context. The latter include PES activities that did not induce a loss of income, but instead worked as an upfront incentive for participants to do what PES activities required (independently if they had planned to do such activities anyway) [39,40,43,45,51,71]; partnered with local and/or external organizations to provide technical support and reduce transaction costs [43,71]; induced local behavioral change and led to practices that diminished resource use, or halted land-use change $\left[57^{\bullet \bullet}, 71\right]$; and did not involve a major departure from existing land-use management and cultural practices [40,53]. Some scholars highlight the importance of providing long-term and periodically adjusted payments to balance participants' changing opportunity and transaction costs over time [40,49], as well as preventing PES implementation in areas with unclear tenure situations or weakly enforced property rights $\left[47,48^{\bullet \bullet}, 53\right]$.

Not all articles concerned with effectiveness refer explicitly to additionality and those referring to it include both effective and non-effective PES schemes. PES schemes have been judged additional when it has been considered that the desired land-use management activities or expected service delivery would not have been implemented or achieved without PES incentives $\left[48^{\bullet \bullet}, 50,52,54,58\right]$. PES schemes have been judged as non-additional by the correspondent authors when PES activities have concentrated on land-use areas with low or zero risk of deforestation [39,41,72], and two of these cases have been also - and counter-intuitively - considered effective on the grounds that payments have contributed to maintain forest cover (despite a low level of additionality) [37,71]. Some authors highlight the difficulty of assessing PES additionality based on project design and existing data [53] or of attributing changes in land use or service flows to PES incentives [59]. Only two of the articles included in our sample consider the PES case efficient, understood as a reduction over time of the total costs per unit of service delivery or habitat provision of the given PES initiative $\left[55^{\circ \bullet}, 71\right]$. Four articles refer to efficiency only vaguely, considering the PES program inefficient if non-additional [39,41], or indicating how the PES initiative could reduce administrative expenses or increase funding levels in the future to become less costly per unit of PES service or targeted area $[50,61]$.

\section{Equity}

Figure 1 above (see Supplementary Table 2 for extended information) includes 24 articles examining the equity outcomes of 24 different PES schemes, with 32 analytical observations (\# bullet points). We classified the author(s)' analytical approach to equity following a three-tiered framework: (a) equity in access, if the author(s) examined local people's ability to participate in the PES program; (b) equity in decision-making, if the author(s) analyzed participants' perceived fairness in project decision-making procedures; and (c) equity in outcome, if the author(s) focused on the impact and distribution of project outcomes, including income, across participants [62,69].

As noted in the introduction, we recognize that the equity dimensions of PES design and implementation are prone to subjective analysis, since they rely on the scholar(s)' own interpretation of who is legitimately entitled to participate in a given scheme and who has been left out, or through local people's own perspective of what is fair. But some equity aspects can also be analyzed objectively, for example measuring changes in relative income, or participation rates and voting procedures in meetings. For this reason it is important to be precise about the methods, data and the indicators used to infer the direction of such outcomes and, for this purpose, we have distinguished between studies relying on quantitative data (e.g. minutes of PES meetings, participation and income data from household surveys) from studies based on qualitative interviews and personal observations.

Authors looking exclusively at equity in access mostly rely on informal interviews [39], program and project secondary data $[40,63]$, and only one on household and village surveys [51]. Those concerned with equity in outcome use interviews, focus groups and/or secondary data $\left[49,57^{\bullet \bullet}, 70\right]$, multi-criteria analysis [43], or only 
program and project secondary data $[44,71]$. Analyses that combine these two dimensions and/or also look at equity in decision-making rely on qualitative research methods and/ or secondary data $[45,46,52,59,62,65,69,71,42]$, surveys, regressions and/or inequality indices $\left[60,61,67^{\bullet \bullet}, 66\right]$. One can observe that there are only five studies that rely on quantitative data from surveys to draw lessons about access, decision-making and outcome. This does not invalidate the findings of the majority of equity-related studies but suggests that there is ample scope for developing more quantitative approaches to provide complementary 'measures' of equity outcomes. Seemingly, only six of the articles focused on equity aspects pay attention to decision-making during the design and implementation phase of PES schemes and explain who has been included and/or excluded in such processes. Among these, only two draw attention to unequal bargaining power in PES design [46,62], while none finds evidence of rent seeking by powerful actors, in contrast to literature expectations $\left[73^{\circ}\right]$.

PES schemes considered equitable as well as environmentally effective encompass national PES programs [45,52,64], and donor or NGO-driven schemes $\left[40,57^{\bullet \bullet}, 71\right]$. PES schemes considered unfair in one or more equity dimensions can be considered either effective $[39,43,46,49,51,69-71,42]$ or ineffective $[44,59,70]$, but many have not been judged in this regard [61$\left.63,67^{\bullet \bullet}, 68,69,66\right]$. Social conflict has been reported in nine PES schemes $\left[43,46,62,67^{\bullet}, 68-70,66\right]$. Some PES activities are reported to have encouraged and ensured the participation of poor and non-poor households in their design and implementation [40]; pursued gender equity [45,52]; empowered local communities through devolved rights in resource management [52]; and have led to a fair distribution of material and/or non-material outcomes across communities and individuals $\left[52,57^{\bullet \bullet}, 71\right]$.

By contrast, other PES schemes have widened the local income wealth gap, often unintentionally and as a result of unfavorable local tenure and political conditions [44,62,69], such as in Mexico's PES program where formal land right-holders have controlled access to payments at village level and have tended to distribute less to nonright-holders $\left[46,67^{\circ}\right]$, or in Tanzania where the poorest households do not have enough land to dedicate to PES activities [59]. As already noted above, both 'poor' and 'rich' households' participation in PES schemes has to do with actual or perceived costs of enrolment, cultural suitability of practices and the latter's fit with local environmental discourses $\left[49,62,67^{\bullet \bullet}\right]$. Some of the scholars' proposals to address PES schemes' underperformance in procedural and distributional terms include further incentivizing poor landowners or the landless, who often experience higher opportunity and transaction costs, and providing them with additional external support [43]; supporting transparent and wide benefit sharing by community-based institutions $\left[67^{\bullet \bullet}, 71\right]$, guaranteeing tenure security for the landless and non-formal rightholders; and improving the value chains of related markets, particularly sustainably harvested timber, so as to increase livelihood gains [43].

\section{Renewing the PES research agenda}

Our review confirms that PES implementation in the (sub-)tropics encompass distinct implementation approaches that diverge in conservation goals, scale of implementation and funding approaches. Related research captures the heterogeneity of PES schemes that has been widely noted and referred to in existing literature and reviews $\left[5^{\bullet}, 74,75\right]$. The size of our database did not allow for any relevant statistical inference to test any likely relationship between the types of PES analyzed, the scale of implementation, the targeted tenure system and the scheme's performance in environmental and equity terms. However, we can conclude that scholars report, on average, more positive environmental outcomes in PES schemes than they report positive outcomes in terms of equity. Spatial and/or econometric assessments related to effectiveness are more able to provide insights on the relative level of environmental additionality of PES schemes, that is, being able to compare PES participants' and non-PES participants' environmental performance controlling for independent variables and confounding factors $\left[47,48^{\bullet \bullet}, 51,53,55^{\bullet \bullet}\right]$. By contrast, qualitative research seems more able to provide insights on equity, with a majority of schemes being judged unfair at procedural and/or distributive levels.

Positive reporting on equity is mostly based on secondary and project management data - columns 7 and 8 of Supplementary Table 2 - (except for Ref. $\left[57^{\bullet \bullet}\right]$ ), while negative reporting often relies on more extensive fieldwork and primary data collection (except for Refs. $[39,44,63,71,42])$. The size of our database does not allow us to categorically affirm that more independent and lengthy engagement in the field reveals equity-related challenges more effectively. However, it enables us to confirm that equity-related evidence is better captured through qualitative analyses derived from interviews and focus groups; very few scholars are able to quantify aspects of equity, such as the impact of PES payments on income inequality.

We have noted above a set of context-dependent (including local ecologies) and scheme design and implementation conditions that are conducive to, or impede the realization of positive effectiveness and equity effects. Regarding the first set of conditions, effectiveness and equity are more likely to be realized when PES land management activities fit with locally known management practices and resource use culture and if they fit with the mandate of local resource management institutions, particularly if PES involves social collectives (e.g. a community). Context-dependent conditions include land 
tenure relations, mediated by local governance institutions, and the extent to which the latter determine who can get involved in the PES scheme, and who can benefit and by how much. Additionally, local opportunity costs determine the extent to which the payment is attractive to land users - leading to increased effectiveness when payments exceed such value-, as well as the time horizon during which payments are delivered - with effectiveness and equity increasing the longer payments are disbursed. As for scheme design, key aspects to foster performance across the two dimensions include long-term involvement of PES promoters with local recipients, in order to provide the necessary knowledge and expertise, as well as promoters' ability to adapt the PES project as tenure relations and land management costs change over time.

Our review also demonstrates that analyses of effectiveness and equity in PES schemes of tropical and subtropical regions have not paid attention to economic costs data, such as the opportunity cost of alternative land use activities, or the transaction costs of program management and monitoring $\left[5^{\circ}\right]$. This is surprising given that effectiveness would need to be related to actual land management costs in order to find out the level of costeffectiveness and to draw insights on PES efficiency over time. The lack of studies on PES cost-effectiveness has been explained by the fact that most schemes in the global South lack clear metrics to quantify the ecosystem services being delivered, and thus the corresponding associated costs. Those schemes focused on carbon are the most notable exception [76]. However, we argue that, while cost constraints are important, lack of reflection as regards cost-effectiveness is also related to insufficient attention to the issue and the common inability of researchers to access data on opportunity costs, and project start-up, transaction and running costs.

The fact that the methodological approaches chosen by scholars to investigate PES performance in terms of environmental effectiveness and social equity differ broadly, responds to the variety of research budgets available and the scientific schools interested in understanding this conservation tool, which range from landuse scientists to economists, anthropologists and critical geographers. However, we think that future PES research would benefit from some level of analytical integration and coordinated research effort to holistically understand the environmental and social outcomes that PES could generate if well targeted and fairly implemented by practitioners. In doing so, scientific research could be more helpful in providing sound and more coherent evidence to PES implementing actors, governments and both donors and service 'buyers'.

The relationship between effectiveness and equity in PES has already been theorized $\left[21^{\bullet \bullet}, 77\right]$ but our review
Box 1 Elements of a future PES research strategy - Activity (A) and Goal (G)

Practitioner-informed meta-analysis of PES

- (A) to develop a global comparative analysis of case studies with inputs provided by PES managers and knowledgeable researchers (G) to draw relevant and shared insights on PES design and implementation

Larger and more cooperative research projects

(A) to generate analyses of PES implementation informed by pane data, in cooperation with practitioners and based on long-term funding and cooperation

(G) to identify PES impacts on environmental and social conditions, controlling for confounding factors; and to investigate interactions between incentives, individual and collective behavior, wellbeing and local institutions

Multiple methods, data \& outcome variables

- (A) to deploy multi-method, and multi-disciplinary evaluative frameworks

(G) to combine insights from different research techniques to draw a complete understanding of PES effects on local and regional

ecologies, as well as on socio-economic and institutional conditions

suggests that there is still a weak link between the two dimensions in empirical studies. This is reflected in the central vertical column and horizontal row of Figure 1 which refer to several articles that do not reflect on PES effectiveness or equity outcomes. A future PES strategy (Box 1) can concentrate on a number of elements. First, scholars can continue to pursue the development of global reviews, following systematic review protocols, and ideally develop a comparable database of PES cases worldwide that can help identifying challenges and trends in PES design and implementation, looking at both effectiveness and equity. Those interested particularly in equity could also consider the challenge of developing syntheses of existing narratives on PES in a way that can be complementary to other reviews based on larger data and more systematic syntheses.

Second, there should be a focus on larger research projects that could follow PES implementation in multiple locations, focusing on one or various PES typologies, and based on a shared research framework - drawing, for example, on similar experiences in common-pool resource management and rural livelihoods research $[78,79]$. These projects should be developed in partnership with PES practitioners, not only to access sites over time for research purposes but to develop locally-informed 'theories of change' that could be tested during and/or after PES implementation. As it has been suggested elsewhere $\left[80,81^{\bullet \bullet}\right]$, coming up with contextspecific hypotheses related to environmental and socio-economic outcomes is fundamental to rule out alternative explanations of positive or negative change - that could be wrongly attributed to PES activities-, and to provide more accurate lessons for practitioners and donors. 
Third, PES research should rely on robust data and methods. Spatial land use data from remote sensing, complemented with on-the-ground monitoring transects, have been mostly applied to understand changes in the correspondent ecological outcome variables, such as forest cover or plant diversity. As regards equity outcomes, surveys and interviews have been used to reflect on PES procedural and distributional effects, such as presence of conflict, changes in resource governance, impact on relative income, and benefit sharing. The use of coupled ecological and socio-economic data in econometric matching techniques with difference-indifference regression models can be helpful to compare performance between PES and non-PES sites of selected variables.

Precisely, involving control groups that act as counterfactuals and panel datasets of ecological and socio-economic data in PES assessment frameworks would be consistent with an increasingly common approach in impact assessments of development and conservation policy [82-84]. We recognize that such an approach involves a set of challenges related to the possibility of selecting valid land-use polygons, village and household controls, particularly in contexts of poor socio-economic and governance data availability, as well as the more recurrent problems in panel data research, including data gathering costs, data consistency and changing circumstances in both project and control groups, for example, due to migration processes. Connecting well-grounded 'theories of change' with measures of effect means that many studies of PES initiatives will benefit from combining research methods, and qualitative work will continue to be critical to understand how people subjectively think and feel about any observed ecological and equity effects derived from PES.

In conclusion, this article set out to review scholarship literature on PES implementation in tropical and subtropical regions. Our database rendered a limited number of (case) studies, which suggests that first-hand empirical evidence on ongoing schemes might be scarcer than one might think given the popularity of the policy mechanism. Seemingly, we have demonstrated that PES schemes appear to be more effective in environmental terms than socially equitable. This is probably our most worrying finding given current grounded calls for incorporating equity criteria in PES design. We have identified critical methodological gaps related to developing panel data and control-based assessments of PES distributional outcomes, particularly in relation to payment effects on household or collective incomes. In light of these findings, we have advocated for a more multi-disciplinary and integrated wave of empirical research that, on the one hand, builds on and supports the evolving and growing literature on conservation policy impact assessment and, on the other, relies on practitioners as key research partners and on PES and research donors as key funding supporters.

\section{Acknowledgements}

Laura Calvet-Mir and Esteve Corbera acknowledge financial support of the Biodiversa Framework Project INVALUABLE: Values, Markets, and Policies for Biodiversity and Ecosystem Services (PRI-PIMBDV-20111072). Esteve Corbera is also funded by the Spanish Research, Development and Innovation Secretariat through a 'Ramón y Cajal' research fellowship (RYC-2010-07183). Adrian Martin and Nicole GrossCamp acknowledge financial support from the Economic and Social Research Council (Conservation, Markets and Justice, ES/K005812/1). We are grateful to Driss Ezzine de Blas, Sven Wunder, Jakub Kronenberg, Géraldine Froger, and an anonymous for their constructive comments on earlier versions of this manuscript.

\section{Appendix A. Supplementary data}

Supplementary material related to this article can be found, in the online version, at http://dx.doi.org/10. 1016/j.cosust.2015.06.001.

\section{References and recommended reading}

Papers of particular interest, published within the period of review, have been highlighted as:

- of special interest

-• of outstanding interest

1. Gutman P: Ecosystem services: foundations for a new ruralurban compact. Ecol Econ 2007, 62:383-387.

2. Potter CA, Wolf SA: Payments for ecosystem services in relation to US and UK agri-environmental policy: disruptive neoliberal innovation or hybrid policy adaptation? Agric Human Values 2014, 31:397-408.

3. Corbera E: Problematizing REDD+ as an experiment in payments for ecosystem services. Curr Opin Environ Sustain 2012, 4:612-619.

4. McElwee PD: Payments for environmental services as neoliberal market-based forest conservation in Vietnam: Panacea or problem? Geoforum 2012, 43:412-426.

5. Wunder S, Engel S, Pagiola S: Taking stock: a comparative - analysis of payments for environmental services programs in developed and developing countries. Ecol Econ 2008, 65:834852.

One of the first published academic synthesis of PES institutional conditions and related performance. The authors distinguish two broad typologies of PES initiatives, that is, user-financed and governmentfinanced, finding significantly different outcomes as regards targeting approaches, conditionality and pursued objectives. The authors provide insights on how PES could be more effective and cost-efficient.

6. Huang M, Upadhyaya SK, Jindal R, Kerr J: Payments for watershed services in Asia: a review of current initiatives. J Sustain Forestry 2009, 28:551-575.

7. Dillaha T et al.: Payments for watershed services in developing countries. American Society of Agricultural and Biological Engineers - Conference on 21st Century Watershed Technology: Improving Water Quality and Environment 2008. 2008:176-184.

8. Ferraro PJ: Regional review of payments for watershed services: sub-Saharan Africa. J Sustain Forest 2009, 28:525-550.

9. Southgate D, Wunder S: Paying for watershed services in Latin America: a review of current initiatives. J Sustain Forest 2009, 28:497-524.

10. Jindal R, Swallow B, Kerr J: Forestry-based carbon sequestration projects in Africa: potential benefits and challenges. Nat Res Forum 2008, 32:116-130.

11. Martin-Ortega J, Ojea E, Roux C: Payments for water ecosystem services in Latin America: a literature review and conceptual model. Ecosyst Services 2013, 6:122-132. 
12. Milne S, Niesten E: Direct payments for biodiversity conservation in developing countries: practical insights for design and implementation. ORYX 2009, 43:530-541.

13. Myers N, Mittermeler RA, Mittermeler CG, Da Fonseca GAB, Kent J: Biodiversity hotspots for conservation priorities. Nature 2000, 403:853-858.

14. Geist HJ, Lambin EF: Proximate causes and underlying driving forces of tropical deforestation. BioScience 2002, 52:143-150.

15. Fisher B, Christopher T: Poverty and biodiversity: measuring the overlap of human poverty and the biodiversity hotspots. Ecol Econ 2007, 62:93-101.

16. Adams WM et al.: Biodiversity conservation and the eradication of poverty. Science 2004, 306:1146-1149.

17. Ferraro PJ: ECOLOGY: direct payments to conserve biodiversity. Science 2002, 298:1718-1719.

18. Wunder S: The efficiency of payments for environmental services in tropical conservation: essays. Conserv Biol 2007, 21:48-58.

19. Sikor T, Martin A, Fisher J, He J: Toward an empirical analysis of justice in ecosystem governance. Conserv Lett 2014 http:// dx.doi.org/10.1111/conl.12142. n/a-n/a.

20. Corbera E, Pascual U: Ecosystem services: heed social goals Science 2012, 335:655-656.

21. Pascual $\cup$ et al.: Social equity matters in payments for •• ecosystem services. BioScience 2014.

The article demonstrates that effectiveness and equity cannot be disconnected in conservation practice and evaluation. It shows how the equity impacts of PES can create positive and negative feedbacks on environmental outcomes. It calls for better engagement between the social and ecological science communities to understand the relationships and trade-offs between efficiency, equity, and ecological performance.

22. De Koning GHJ, Benítez PC, Muñoz F, Olschewski R: Modelling the impacts of payments for biodiversity conservation on regional land-use patterns. Landsc Urban Plann 2007 83:255-267.

23. Wünscher $T$, Engel $S$, Wunder $S$ : Spatial targeting of payments for environmental services: a tool for boosting conservation benefits. Ecol Econ 2008, 65:822-833.

24. Bulte EH, Boone RB, Stringer R, Thornton PK: Elephants or onions? Paying for nature in Amboseli, Kenya. Environ Dev Econ 2008, 13:395-414.

25. Barton DN et al.: Environmental service payments: evaluating biodiversity conservation trade-offs and cost-efficiency in the Osa Conservation Area, Costa Rica. J Environ Manage 2009, 90:901-911.

26. Quintero M, Wunder S, Estrada RD: For services rendered? Modeling hydrology and livelihoods in Andean payments for environmental services schemes. Forest Ecol Manage 2009, 258:1871-1880.

27. Arias ME, Cochrane TA, Lawrence KS, Killeen TJ, Farrell TA: Paying the forest for electricity: a modelling framework to market forest conservation as payment for ecosystem services benefiting hydropower generation. Environ Conserv 2011, 38:473-484

28. Fletcher R, Breitling J: Market mechanism or subsidy in disguise? Governing payment for environmental services in Costa Rica. Geoforum 2012, 43:402-411.

29. Roth RJ, Dressler W: Market-oriented conservation governance: the particularities of place. Geoforum 2012, 43:363-366.

30. Goldman-Benner RL et al: : Water funds and payments for ecosystem services: practice learns from theory and theory can learn from practice. ORYX 2012, 46:55-63.

31. Zhang W, Pagiola S: Assessing the potential for synergies in the implementation of payments for environmental services programmes: an empirical analysis of Costa Rica. Environ Conserv 2011, 38:406-416.
32. Rico García-Amado L, Ruiz Pérez M, Barrasa García S: Motivation for conservation: assessing integrated conservation and development projects and payments for environmental services in la sepultura biosphere reserve, mexico, chiapas. Ecol Econ 2013, 89:92-100.

33. Kosoy N, Corbera E, Brown K: Participation in payments for ecosystem services: case studies from the Lacandon rainforest, Mexico. Geoforum 2008, 39:2073-2083.

34. Fauzi A, Anna Z: The complexity of the institution of payment for environmental services: a case study of two Indonesian PES schemes. Ecosyst Services 2013, 6:54-63.

35. Nelson F et al.: Payments for ecosystem services as a framework for community-based conservation in northern Tanzania. Conserv Biol 2010, 24:78-85

36. Pirard R: Payments for Environmental Services (PES) in the public policy landscape: 'Mandatory' spices in the Indonesian recipe. Forest Policy Econ 2012, 18:23-29.

37. Farley KA, Anderson WG, Bremer LL, Harden CP: Compensation for ecosystem services: an evaluation of efforts to achieve conservation and development in Ecuadorian páramo grasslands. Environ Conserv 2011, 38:393-405.

38. Pagiola $\mathrm{S}$ et al.: Paying for biodiversity conservation services: experience in Colombia, Costa Rica, and Nicaragua. Mountain Res Dev 2005, 25:206-211.

39. Sierra R, Russman E: On the efficiency of environmental service payments: a forest conservation assessment in the Osa Peninsula, Costa Rica. Ecol Econ 2006, 59:131-141.

40. Pagiola $S$ et al.: Paying for the environmental services of silvopastoral practices in Nicaragua. Ecol Econ 2007, 64:374385.

41. Sánchez-Azofeifa GA, Pfaff A, Robalino JA, Boomhower JP: Costa Rica's payment for environmental services program: intention, implementation, and impact. Conserv Biol 2007 21:1165-1173.

42. Asquith NM, Vargas MT, Wunder S: Selling two environmenta services: in-kind payments for bird habitat and watershed protection in Los Negros, Bolivia. Ecol Econ 2008, 65:675-684.

43. Locatelli B, Rojas V, Salinas Z: Impacts of payments for environmental services on local development in northern Costa Rica: a fuzzy multi-criteria analysis. Forest Policy Econ 2008, 10:275-285.

44. Pagiola S: Payments for environmental services in Costa Rica Ecol Econ 2008, 65:712-724

45. Turpie JK, Marais C, Blignaut JN: The working for water programme: evolution of a payments for ecosystem services mechanism that addresses both poverty and ecosystem service delivery in South Africa. Ecol Econ 2008, 65:788-798.

46. Corbera E, Soberanis CG, Brown K: Institutional dimensions of payments for ecosystem services: an analysis of Mexico's carbon forestry programme. Ecol Econ 2009, 68:743-761.

47. Honey-Rosés J, López-García J, Rendón-Salinas E, PeraltaHiguera A, Galindo-Leal C: To pay or not to pay? Monitoring performance and enforcing conditionality when paying for forest conservation in Mexico. Environ Conserv 2009, 36:120-128.

48. Honey-Rosés J, Baylis K, Ramírez MI: A spatially explicit

-• estimate of avoided forest loss. Conserv Biol 2011 25:1032-1043.

Thorough analysis of the effectiveness of a local PES scheme in centra Mexico. The authors use a spatial-matching estimator that matches covariates among polygons and their neighbours to measure payments effect on avoided forest disturbance and deforestation. They find that PES resulted very effective in conserving key forest habitats for a migratory butterfly species but less so in halting deforestation over the total program area.

49. Van Hecken G, Bastiaensen J: Payments for ecosystem services in Nicaragua: do market-based approaches work? Dev Change 2010, 41:421-444. 
50. Wendland KJ et al.: Targeting and implementing payments for ecosystem services: opportunities for bundling biodiversity conservation with carbon and water services in Madagascar. Ecol Econ 2010, 69:2093-2107.

51. Hegde R, Bull GQ: Performance of an agro-forestry based payments-for-environmental-services project in Mozambique: a household level analysis. Ecol Econ 2011 71:122-130.

52. Naidoo R, Weaver LC, De Longcamp M, Du Plessis P: Namibia's community-based natural resource management programme an unrecognized payments for ecosystem services scheme. Environ Conserv 2011, 38:445-453.

53. Scullion J, Thomas CW, Vogt KA, Pérez-Maqueo O, Logsdon MG: Evaluating the environmental impact of payments for ecosystem services in Coatepec (Mexico) using remote sensing and on-site interviews. Environ Conserv 2011, 38:426434.

54. Alix-Garcia JM, Shapiro EN, Sims KRE: Forest conservation and slippage: evidence from mexico's national payments for ecosystem services program. Land Econ 2012, 88:613-638.

55. Arriagada RA, Ferraro PJ, Sills EO, Pattanayak SK, Cordero-

- Sancho S: Do payments for environmental services affect forest cover? A farm-level evaluation from Costa Rica. Land Econ 2012, 88:382-399.

Multi-disciplinary study that estimates the impact of Costa Rica's PES program in a specific region of the country, using data from remote sensing and household surveys, and other methods that include partial identification with weak assumptions, difference-in-differences matching estimators, and tests of sensitivity to unobservable heterogeneity. Authors find that PES has resulted in increased forest cover in targeted farms, compared to observed forest cover loss in control farms. Authors acknowledge that a partnership with implementing organisations was key to access good data, and they advocate for ex ante PES experimental designs before implementation.

56. Garbach K, Lubell M, DeClerck FAJ: Payment for ecosystem services: the roles of positive incentives and information sharing in stimulating adoption of silvopastoral conservation practices. Agric Ecosyst Environ 2012, 156:27-36.

57. Gross-Camp ND, Martin A, McGuire S, Kebede B, Munyarukaza J:

- Payments for ecosystem services in an African protected area: exploring issues of legitimacy, fairness, equity and effectiveness. Oryx 2012, 46:24-33.

The authors, in partnership with a local NGO and the national government, develop a pilot PES scheme in Rwanda and explore its environmenta effectiveness, legitimacy and distributional outcomes employing surveybased and observation methods. The authors conclude that payments are effective in reducing illicit resource collection activities, with positive spillover effects over non-PES treated forest units. They do not observe significant negative effects on households' consumption and wealth as a result of forest resource management constraints, but they identify households who perceive payments distribution and subsequent management rules unfair and negative for their livelihoods.

58. Hayes TM: Payment for ecosystem services, sustained behavioural change, and adaptive management: peasant perspectives in the Colombian Andes. Environ Conserv 2012, 39:144-153.

59. Lopa $D$ et al.: Towards operational payments for water ecosystem services in Tanzania: a case study from the Uluguru Mountains. ORYX 2012, 46:34-44.

60. Newton P, Nichols ES, Endo W, Peres CA: Consequences of actor level livelihood heterogeneity for additionality in a tropical forest payment for environmental services programme with an undifferentiated reward structure. Global Environ Change 2012, 22:127-136.

61. Zbinden S, Lee DR: Paying for environmental services: an analysis of participation in Costa Rica's PSA program. World Dev 2005, 33:255-272.

62. Corbera E, Brown K, Adger NW: The equity and legitimacy of markets for ecosystem services. Dev Change 2007, 38:587-613.

63. Muñoz-Piña C, Guevara A, Torres JM, Braña J: Paying for the hydrological services of Mexico's forests: analysis, negotiations and results. Ecol Econ 2008, 65:725-736.
64. De Koning $\mathrm{F}$ et al.: Bridging the gap between forest conservation and poverty alleviation: the Ecuadorian Socio Bosque program. Environ Sci Policy 2011, 14:531-542.

65. Milne S, Adams B: Market Masquerades: uncovering the politics of community-level payments for environmental services in Cambodia. Dev Change 2012, 43:133-158.

66. Krause T, Collen W, Nicholas KA: Evaluating safeguards in a conservation incentive program: participation, consent, and benefit sharing in indigenous communities of the Ecuadorian Amazon. Ecol Soc 2013, 18

67. Rico García-Amado L, Pérez MR, Escutia FR, García SB, Mejía EC:

- Efficiency of payments for environmental services: equity and additionality in a case study from a biosphere reserve in Chiapas, Mexico. Ecol Econ 2011, 70:2361-2368.

Analysis of the equity, additionality and perceptions of a PES scheme in Mexico, showing a dual response in equity and additionality, depending on land tenure. PES have an egalitarian effect within landowners and landless groups but broaden the gap between them. Additionality is low for landowners and high for the landless people in the community.

68. Couto Pereira SN: Payment for environmental services in the amazon forest: how can conservation and development be reconciled? J Environ Dev 2010, 19:171-190.

69. Corbera E, Kosoy N, Martínez Tuna M: Equity implications of marketing ecosystem services in protected areas and rural communities: case studies from Meso-America. Global Environ Change 2007, 17:365-380.

70. Kosoy N, Martinez-Tuna M, Muradian R, Martinez-Alier J: Payments for environmental services in watersheds: Insights from a comparative study of three cases in Central America. Ecol Econ 2007, 61:446-455.

71. Clements Tetal: Payments for biodiversity conservation in the context of weak institutions: comparison of three programs from Cambodia. Ecol Econ 2010, 69:1283-1291.

72. Pagiola S, Arcenas A, Platais G: Can payments for environmental services help reduce poverty? An exploration of the issues and the evidence to date from Latin America. World Dev 2005, 33:237-253.

73. Kronenberg J, Hubacek K: Could payments for 'ecosystem - $\quad$ services create an ecosystem service curse'? Ecol Soc 2013, 18

Conceptual piece reflecting on the risks of PES implementation from a political economy perspective. The authors argue that if PES programs and payments are upscaled considerably poor countries will face problems similar to resource-cursed countries, namely rent seeking, unequal bargaining power of buyers and sellers, and volatility of PES incentives, which are all related to the quality of institutions. Based on emerging evidence of these phenomena, the authors argue that PES should be designed to pay attention to distribution of property rights and transparency, decentralization of revenues, and capacity building to ensure further development opportunities.

74. Muradian R, Corbera E, Pascual U, Kosoy N, May PH: Reconciling theory and practice: an alternative conceptual framework for understanding payments for environmental services. Ecol Econ 2010, 69:1202-1208.

75. Schomers S, Matzdorf B: Payments for ecosystem services: a review and comparison of developing and industrialized countries. Ecosyst Services 2013, 6:16-30.

76. Kroeger T: The quest for the 'optimal' payment for environmental services program: ambition meets reality, with useful lessons. Forest Policy Econ 2013, 37:65-74.

77. Pascual U, Muradian R, Rodríguez LC, Duraiappah A: Exploring the links between equity and efficiency in payments for environmental services: a conceptual approach. Ecol Econ 2010, 69:1237-1244.

78. Chhatre A, Agrawal A: Forest commons and local enforcement. Proc Natl Acad Sci U S A 2008, 105:13286-13291.

79. Angelsen A et al.: Environmental income and rural livelihoods: a global-comparative analysis. World Dev 2014, 64(Suppl 1):S12S28. 
80. Ferraro PJ, Pattanayak SK: Money for nothing? A call for empirical evaluation of biodiversity conservation investments. PLoS Biol 2006, 4:e105.

81. Ferraro PJ, Hanauer MM: Advances in measuring the

- environmental and social impacts of environmental programs. Annual Rev Environ Res 2014, 39:495-517.

This review highlights the key components of what should ideally become a mainstream approach to environmental policy design and evaluation, including PES programs. This would require scholars to identify and eliminate rival explanations for observed empirical patterns; develop definitions of causal effects in terms of potential outcomes, both observable outcomes and unobservable, counterfactual outcomes; and to make transparent the assumptions required for causal inference of policy outcomes.

82. White $\mathrm{H}$ : Theory-based impact evaluation: principles and practice. J Dev Effectiveness 2009, 1:271-284.

83. Miteva DA, Pattanayak SK, Ferraro PJ: Evaluation of biodiversity policy instruments: what works and what doesn't? Oxf Rev Econ Policy 2012, 28:69-92.

84. Baylis $\mathrm{K}$ et al.: Mainstreaming impact evaluation in nature conservation. Conserv Lett 2015 http://dx.doi.org/10.1111/ conl.12180. 